\title{
Isotretinoin in Severe Peanut- and Soy-Allergic Patients: Is it Safe or Not?
}

Denorme $\mathrm{P}^{1 *}$, Schrijvers $\mathrm{R}^{2,3 *}$, Van Hoeyveld $\mathrm{E}^{4}$, Verfaillie $\mathrm{S}^{5}$, Bullens D ${ }^{2,6}$, Morren MA ${ }^{1}$, Breynaert $\mathrm{C}^{2,3}$

${ }^{1}$ University Hospitals Leuven, Department of Dermatology, Leuven, Belgium

${ }^{2} \mathrm{KU}$ Leuven Department of Microbiology, Immunology and Transplantation, Allergy and Clinical Immunology Research Group, Leuven, Belgium

${ }^{3}$ University Hospitals Leuven, Department of General Internal Medicine, Allergy and Clinical Immunology, Leuven, Belgium.

${ }^{4}$ University Hospitals Leuven, Laboratory Medicine, Leuven, Belgium

${ }^{5}$ Independent Dermatologist, Leuven, Belgium

${ }^{6}$ University Hospitals Leuven, Department of Pediatrics, Pediatric Allergology, Leuven, Belgium

*These authors share first co-authorship.

J Investig Allergol Clin Immunol 2019; Vol. 29(2): 146-148 doi: $10.18176 /$ jiaci.0352

Key words: Peanut. Soy. Soybean oil. Isotretinoin. Allergy.

Palabras clave: Cacahuete. Soja. Aceite de soja. Isotretinoína. Alergia.

Isotretinoin is contraindicated in patients with peanut allergy, soy allergy, or both. We present a case of successful oral challenge with isotretinoin in a patient with both primary peanut and soy allergy and suggest a stepwise work-up.

A 25-year-old man with severe acne and a history of allergic asthma, rhinoconjunctivitis, and allergic reactions to peanut in childhood was referred to the allergy department by his dermatologist to evaluate the safety of isotretinoin. The prescribing information leaflet states that isotretinoin is contraindicated in patients with known soybean or peanut allergy, owing to the risk of potential cross-reactivity. All oral isotretinoin formulations in Belgium contain soybean oil. However, data about the safety of isotretinoin in patients with potential severe peanut and/or soybean allergy are scarce [1-4].

The patient had avoided peanuts and soybean products since childhood because of several allergic reactions involving facial swelling, itching, and dyspnea immediately after eating peanuts or food containing peanut or peanut oil. He had never experienced reactions to soy, although a careful dietary history suggested absence of exposure to soy-containing food. An allergy work-up was performed. Skin prick tests (SPTs) were positive for peanut extract (4+) and soy milk (4+). Specific IgE (sIgE, ImmunoCAP ThermoFisher/Phadia) to the crude extract of peanut and the stable $2 \mathrm{~S}$-albumin seed storage protein of Ara $\mathrm{h} 2$, which is associated with systemic reactions to peanut [5], was $>100 \mathrm{kU} / \mathrm{L}$ in both cases. $\mathrm{sIgE}$ for the other seed storage proteins of peanut (Ara $h 1$ and Ara h 3) was also detected (respectively $>100 \mathrm{kU} / \mathrm{L}$ and $36.30 \mathrm{kU} / \mathrm{L}$ ), with no relevant sensitization to Bet $\mathrm{v} 1$ or lipid 
transfer protein (Ara h 8 and Ara h 9, respectively, $0.12 \mathrm{kU} / \mathrm{L}$ and $0.16 \mathrm{kU} / \mathrm{L})$. sIgE for the crude extract of soy, the stable seed storage proteins of soy (Gly m 5 and Gly m 6, which are associated with severe allergic reactions [6]), and the Bet $\mathrm{v}$ 1-cross-reactive allergen Gly $\mathrm{m} 4$, were respectively $6.82 \mathrm{kU} / \mathrm{L}, 12.70 \mathrm{kU} / \mathrm{L}$, and $<0.10 \mathrm{kU} / \mathrm{L}$ (normal $<0.10 \mathrm{kU} / \mathrm{L}$ ); total $\mathrm{IgE}$ was $915 \mathrm{kU} / \mathrm{L}$. SPTs with the capsule and content of 3 isotretinoin-containing products available in Belgium (Isosupra, Isotretinoine EG, and Roaccutane), all containing soybean oil, were negative. A subsequent open oral challenge with Isotretinoine EG (0.01-0.1-1-10-20-100\%, cumulative dose of $131.11 \%$ [13.11 mg]) was negative. Given the oil content of the capsule, we dissolved the drug in hot milk in order to be able to perform an updosing protocol. After this successful challenge, long-term treatment with isotretinoin was successfully initiated.

Peanut and soy are phylogenetically and antigenetically related and share several homologous proteins. Patients with severe peanut allergy are also at risk of developing severe reactions to soy [7]. Soybean oil still contains soy proteins; therefore, isotretinoin, which contains soybean oil, is contraindicated in patients with known soybean or peanut allergy, owing to the risk of potential cross-reactivity. However, it has been demonstrated that the allergenicity of proteins in soybean oil is reduced with regard to soybean allergy [8]. The only case of potential anaphylaxis after a first dose of isotretinoin was reported in a patient with minor sensitization to soybean (Gly m 41.38 kUA/L) [9]. However, it remains arguable whether isotretinoin was the culprit of the reaction: the 27-year-old patient, with known cashew nut allergy, developed facial swelling only 12 hours after the first dose of isotretinoin and was able to continue the treatment for 3 days. The authors report successful initiation of treatment with isotretinoin in 4 patients with negative SPT and $\operatorname{sigE}$ results for soybean.

Only 3 cases of successful oral provocation with isotretinoin in peanut allergic patients have been reported, and low $\operatorname{sgE}$

Table. Published Cases of Oral Provocation With Isotretinoin in Patients With Soybean and/or Peanut Allergy

\begin{tabular}{|c|c|c|c|c|}
\hline & Case $1^{[1]}$ & Case $2^{[2]}$ & Case $3^{[3]}$ & $\begin{array}{c}\text { Present } \\
\text { Case }\end{array}$ \\
\hline \multicolumn{5}{|l|}{ Skin prick testing } \\
\hline SPT peanut & Positive & Positive & Positive & Positive \\
\hline SPT soy & Negative & NR & Positive & Positive \\
\hline SPT isotretinoin & Negative & Negative & Negative & Negative \\
\hline \multicolumn{5}{|c|}{ Specific IgE (ImmunoCAP) } \\
\hline Total IgE $(\mathrm{kU} / \mathrm{L})$ & 959 & 817 & 4229 & 915 \\
\hline Peanut (kU/L) & 3.93 & NR & 35.7 & $>100$ \\
\hline Ara h $2(\mathrm{kU} / \mathrm{L})$ & 0.72 & 4.12 & 7.97 & $>100$ \\
\hline Ara h $8(\mathrm{kU} / \mathrm{L})$ & NR & 9.74 & 3.72 & 0.12 \\
\hline Ara h $9(\mathrm{kU} / \mathrm{L})$ & NR & NR & NR & 0.16 \\
\hline Soy $(k U / L)$ & $<0.35$ & NR & 0.39 & 10.20 \\
\hline Gly m 5 (kU/L) & NR & NR & NR & 6.82 \\
\hline Gly m $6(\mathrm{kU} / \mathrm{L})$ & NR & NR & NR & 12.70 \\
\hline \multicolumn{5}{|l|}{ Oral challenge } \\
\hline Isotretinoin & Negative & Negative & Negative & Negative \\
\hline
\end{tabular}

Abbreviations. NR, not reported; SPT, skin prick test. for soybean $(0.39 \mathrm{kU} / \mathrm{L})$ was detected in only 1 case, although the patient did not report allergic reactions to soy and was not avoiding soy in his diet (Table) [1-3]. Spierings et al [4] report the successful introduction of isotretinoin in 6 patients with known severe peanut allergy, although they do not report the results of component-specific IgE [4]. Challenge testing in the hospital yielded negative results.

We present an oral challenge strategy for isotretinoin based on increasing doses that is feasible in high-risk patients with severe soybean allergy, peanut allergy, or both. The summary of product characteristics states that oral isotretinoin is contraindicated in patients with known soybean or peanut allergy. Therefore, we suggest, as do other authors, that there is probably only a theoretical risk for allergic reactions to isotretinoin, even in patients with severe primary peanut and/ or soybean allergy [10].

Based on our results and previous case reports, we suggest the following steps before initiation of isotretinoin in patients with potential soybean and/or peanut allergy:

1. Establish a correct diagnosis of soybean and/or peanut allergy based on history, SPT, and determination of $\operatorname{sigE}$ (at least Ara h 2, Gly m 5, and Gly m 6).

2. In the case of Bet v 1-associated soybean and/or peanut allergy, isotretinoin can be started safely at home without precautions.

3. In the case of (severe) primary soybean and/or peanut allergy, depending on the potential risk and need for the regimen, a first intake under medical supervision can be performed with a 1-hour observation period. In high-risk patients and children, oral challenge with isotretinoin dissolved in hot milk can be performed in a hospital setting, as described in the present case.

\section{Funding}

The authors declare that no funding was received for the present study.

\section{Conflicts of Interest}

The authors declare that they have no conflicts of interest.

\section{Previous Presentations}

These data were presented at a National Meeting of the Belgian Society of Allergy and Clinical Immunology on November $25^{\text {th }}, 2017$.

\section{References}

1. Pierret $\mathrm{L}$, Grosber $\mathrm{M}$, Gutermuth J. Is isotretinoin treatment safe in patients with known peanut allergy? J Eur Acad Dermatol Venereol. 2016;30:140-1.

2. Hulstaert E, Van Autryve E, Temmerman L. Is isotretinoin treatment safe in patients with known peanut allergy? Reply. J Eur Acad Dermatol Venereol. 2016;30:376.

3. Alvarez-Arango S, Hou A, Lowes MA, Jerschow E. Isotretinoin treatment in a patient with known peanut allergy and positive IgE test results for soybean. Ann Allergy Asthma Immunol. 2016;117:558-9. 
4. Spierings NM, Natkunarajah J, Bansal A, Ostlere L. Should we be prescribing isotretinoin to patients with peanut allergies? Clin Exp Dermatol. 2015;40:824-5.

5. Kukkonen AK, Pelkonen AS, Makinen-Kiljunen $S$, Voutilainen H, Makela MJ. Ara h 2 and Ara 6 are the best predictors of severe peanut allergy: a double-blind placebo-controlled study. Allergy. 2015;70:1239-45.

6. Holzhauser T, Wackermann O, Ballmer-Weber BK, et al. Soybean (Glycine max) allergy in Europe: Gly m 5 (betaconglycinin) and Gly m 6 (glycinin) are potential diagnostic markers for severe allergic reactions to soy. J Allergy Clin Immunol. 2009;123:452-8.

7. Sicherer SH, Sampson HA, Burks AW. Peanut and soy allergy: a clinical and therapeutic dilemma. Allergy. 2000;55:515-21.

8. Awazuhara H, Kawai H, Baba M, Matsui T, Komiyama A. Antigenicity of the proteins in soy lecithin and soy oil in soybean allergy. Clin Exp Allergy. 1998;28:1559-64.

9. Alden K, Chowdhury MMU, Williams PE, Kalavala M. Protocol for investigation of possible soya allergy in patients being considered for treatment with isotretinoin or alitretinoin. Clinical and Experimental Dermatology. 2016;41:326-7.

10. Spierings NMK, Bansal A, Ostlere L. Peanut allergy and isotretinoin: reply to McCarthy et al. Clin Exp Dermatol. 2017;42:805.

I Manuscript received August 17, 2018; accepted for publication November 13, 2018.

Christine Breynaert

Department of General Internal Medicine Allergy and Clinical Immunology University Hospitals Leuven, Belgium E-mail: Christine.Breynaert@uzleuven.be 